\author{
(online) $=$ ISSN $2285-3642$ \\ ISSN-L = $2285-3642$ \\ Journal of Economic Development, Environment and People \\ Volume 4, Issue 1, 2015 \\ URL: $\underline{\text { http://jedep.spiruharet.ro }}$ \\ e-mail: office jedep@spiruharet.ro
}

\title{
Organic Food Purchase Habits in Hungary
}

\author{
Viktória SZENTE ${ }^{1}$ and Dorisz TORMA ${ }^{2}$ \\ ${ }^{1,2}$ Department of Marketing and Trade, Faculty of Economics, Kaposvár University, Hungary
}

\begin{abstract}
In Hungary organic food market has both demand and supply oriented aspect: several times not necessary products are distributed while the selection and volume of certain products are not satisfactory. Thus our aim was to develop a coordinated benchmark strategy to increase the trade of organic products. To get more details about the Hungarian organic food market we applied the "mystery shopping" method to observe changes in organic food supply and carried out a quantitative survey using a 1,000 member countrywide panel. Our results indicate that organic origin is considered somewhat important for every 4 th respondent, while only $3.7 \%$ of the interviewees paid attention to put organic food products in to their cart. The most serious obstacle is the doubt of surveyed individuals about the authenticity and the all eged benefits of organic products complete with a high perceived price. "Price" is the most influential factor on shopping decision, but the advantageous "constant quality" and "health benefit" factors are just following it. Most of the respondents stated that they buy organic products directly from the producer (27.4\%), but small retail outlets are likewise popular (though to a somewhat lesser extent). In conclusion, there is potential demand for ecological food products in Hungary. Although the proportion of conscious consumers is small; it significantly exceeds the current market share of the products. Consumers should be approached with better prices, smart retailing solutions and through awareness rising.
\end{abstract}

Keywords: organic food; consumer; retail; in-store marketing, strategy

JEL Codes: Q13

\section{Introduction}

In Hungary, 124402 hectares of field space were devoted to producing organic foods in 2011 (Willer\&Lernoud, 2013). Crop production occupies a dominant place in the production structure. The rate of organic animal breeding is lower, and only a small area is currently devoted to non-grain vegetable and fruit production (Biokontroll Hungária, 1998-2012).

Unfortunately, there is no reliable data in Hungary regarding organic food traffic; participation of sales channels are only estimated. Based on these estimates, the traffic of organic food in Hungary is about 30-35 million Euros. This amounts to less than $1 \%$ of national food market traffic. The Hungarian organic food consumption level is even lower, only $0.5-1 \%$ of total consumption (Czeller, 2009; Gauvrit\&Schaer, 2013).

We could see, the market of organic products is quite small in Hungary. However, based on its development potential it has strategic importance (Szakály, 2004). According to GFK Hungária (2005) lifestyle survey, about $65 \%$ of Hungarians consider organic foods the ideal nutriment of future. Researches of Gerwin (1998) and Panyor (2007) shows that 60\% of consumers have bought any kind of organic food in Hungary. In research of Szente et al. (2009) first the interviewers made the consumers familiar with the 


\author{
(online) $=$ ISSN $2285-3642$ \\ ISSN-L = $2285-3642$ \\ Journal of Economic Development, Environment and People \\ Volume 4, Issue1, 2015 \\ URL: $\underline{\text { http://jedep.spiruharet.ro }}$ \\ e-mail: office jedep@spiruharet.ro
}

term main features of organic foods. They asked the consumers questions only after this. It turned out that the majority $(59.2 \%, 710$ persons from 1200$)$ have never bought such a product. The most frequently chosen products were fruits and vegetables (14.4\%), milk and dairy products $(6.9 \%)$ and bakery products (3.4\%). According to the results a significant part of the consumers $(40.1 \%)$ are willing to pay a higher price for organic products. The reasons for paying premium price are mainly to protect their health and to avoid risks of diseases.

Hungarian organic food scarcely appears in retail; consumers can only buy imported, sometimes lower quality products. The market has problems in both supply and demand: they distribute products that are not needed, and certain desired products are absent.

Based on the above, there is a need for considerable developments in the marketing of organic food. The aim of our research is to determine present domestic tendencies and to make strategic proposals to increase the market for organic products. In order to reach our aims we have decided to approach both supply and demand orientation: we have measured both the sellers' (including manufacturers with direct sale) and consumers' side.

\title{
2. Material and Methods
}

\subsection{Sampling}

In order to achieve the set objective, a nationwide representative questionnaire-based survey was given to 1000 participants in Hungary, in 2013. Representativeness for regions and types of settlement was ensured by the applied quoted sampling method. The sample pattern met the quotas previously defined by the Hungarian Central Statistical Office ( $\mathrm{HCSO}$ ). On the assigned settlements a random walking method was used to ensure total randomness in selection (Malhotra, 2008). In the second step, the interviewed person within one household/family was selected by using the so-called birthday-key. The main point of the method is to select that consumer from the family members who has the appropriate age (18 or older) and whose date of birth (birthday) falls closest to the day of the interview (more simply: whoever had their birthday last). With this method randomness was ensured in the second step as well. Refusal was characteristic; the questions were answered in only $68 \%$ of the households.

Since random walking does not ensure the sample is a reflection of the entirety of the population (the number of the female and elderly respondents was higher than the national average), the sample of the people was corrected by multi-dimensional weighing factors (gender and age) (Grafen\& Hails, 2002). After these methods were applied, the sample was representative of the structure of the Hungarian population in all the four aspects (region, type of settlement, gender and age).

\subsection{Analysis of the Data}

During data analysis the suitable mathematical-statistical methods were used. In this ways in every case the percent rates and the significance level were calculated (Grafen\& Hails, 2002). Besides the descriptive 


\author{
(online) $=$ ISSN $2285-3642$ \\ ISSN-L = 2285- 3642 \\ Journal of Economic Development, Environment and People \\ Volume 4, Issue 1, 2015 \\ URL: $\underline{\text { http://jedep.spiruharet.ro }}$ \\ e-mail: office jedep@spiruharet.ro
}

statistics one and two variants analysis were made. The missing values were replaced by a sample mean in each case.

\title{
3. Results and Discussion
}

The first question touched upon the origin of the products: is it important for the consumer to know whether the desired product is organic, local or Hungarian?

Organic origin is considered somewhat important for 4 out of 10 respondent $(38,9 \%)$, while the majority $(59,8 \%)$ is neutral towards this aspect of products. At the same time, in the case of local products, origin is partially or wholly important for as much as $72.9 \%$ of the interviewees. It is worth noting that $62.9 \%$ of those who prefer ecologically farmed food products also consider local origin important. Yet, $48.1 \%$ of those who favor locally produced goods do not consider organic origin important at all.

Similar results were observed by others too: according to the findings of Costanigro et al. (2011) attitudes associated with "local food products" are stronger than that of "ecological food products". The results of Haas et al. (2014) also point to the conclusion that despite their divergent distribution channels, branding, pricing and labeling, organic and local food products are rivals on the American market. Otherwise, some Austrian results are quite promising: according to a survey conducted in Lower Austria, it is exactly this kind of duality that can turn an enterprise into a successful business (Milestad et al., 2010).

In our research, we also asked our respondents to rate how much they care for choosing organic products when buying food (Figure 1).

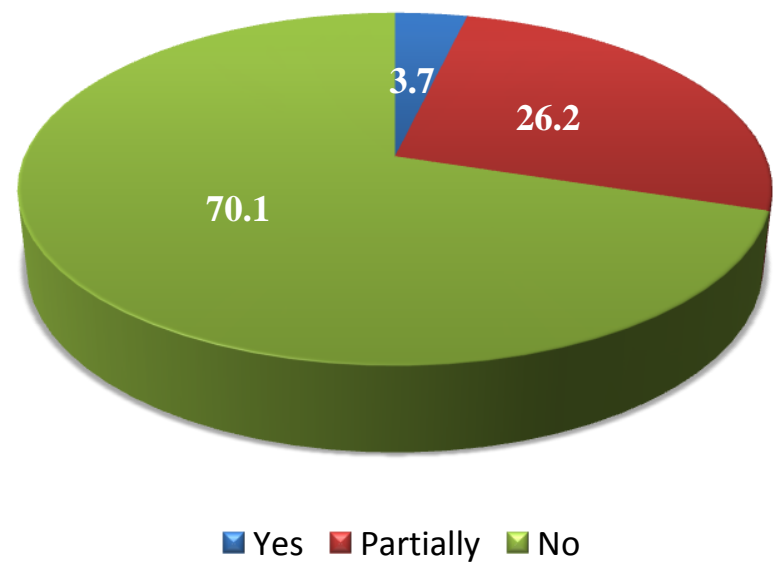

Fig. 1: Willingness of respondents to actually buy organic food products, $\%$ ( $n=1000)$

$3.7 \%$ of the interviewees paid attention to put organic food products into their cart, and $10 \%$ insisted that organic origin is important for them. Consequently, somewhat more than one fourth of the respondents is only planning or would only like to buy the desired products, but due to certain obstacles they withdraw from doing so. Those, who replied with "yes" to organic products are predominantly women 


\author{
(online) $=$ ISSN $2285-3642$ \\ ISSN-L = 2285- 3642 \\ Journal of Economic Development, Environment and People \\ Volume 4, Issue1, 2015 \\ URL: $\underline{\text { http://jedep.spiruharet.ro }}$ \\ e-mail: office jedep@spiruharet.ro
}

(36.0\%), tertiary education graduates (39.9\%), white-collar workers $(41.9 \%)$, or have above average income (45.7\% and $30.8 \%)$. The majority replied with "no" to this question too. The results shown on the above two figures indicate that in addition to the actual buyers, many other respondents consider organic origin an important factor. To understand the underlying causes, we asked those who replied with "no" to specify the obstacles preventing them from buying organic products.

The causes thus obtained are summarized in Figure 2.

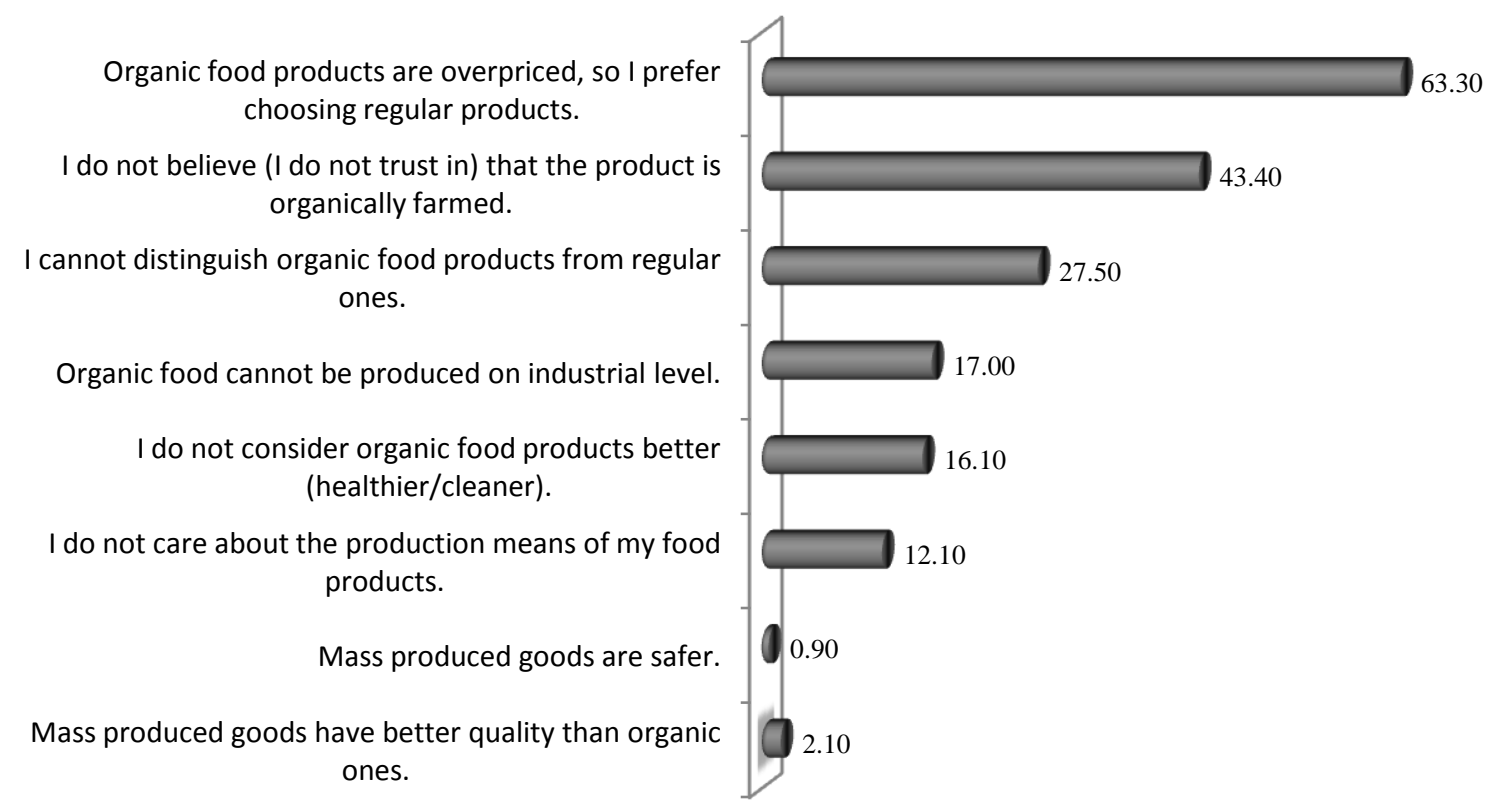

* More than one option was possible.

Fig. 2: Causes for refusing organic products, \% $(n=701)$

The main cause of refusal is the relatively high price; two-third of the surveyed individuals cited this as an obstacle (63.3\%). By summing the results associated with the different factors signaling skepticism, we obtain $79.5 \%$, i.e., the most serious obstacle is the doubt of surveyed individuals about the authenticity and the alleged benefits of organic products. The third argument according to which it is hard to identify the products-problematic for one fourth of the consumers (27.5\%)-might be most easily treated with communication tools. This also draws attention to the problem that distinguishing verified organic food products from normal goods is hard-even these days. Although there are local and EU regulations, consumers can hardly distance the designated "bio-" prefix of foods from that of biotechnological products. What is more, the Hungarian slang term for synthetic cannabinoids "biofü" might also give rise to dangerous associations among the lay consumers. As regards the background variables, the lack of skepticism towards and trust in the health benefits of organic product are correlated with one's level of 


\author{
(online) $=$ ISSN $2285-3642$ \\ ISSN-L = $2285-3642$ \\ Journal of Economic Development, Environment and People \\ Volume 4, Issue 1, 2015 \\ URL: http://jedep.spiruharet.ro \\ e-mail: office jedep@spiruharet.ro
}

education: lowly-educated respondents (up to primary school) and tertiary education graduates are the less skeptic $(p=0,000)$ and the most trustful $(p=0,026)$.

The next question dealt with those factors that have the largest impact on one's organic food purchase (Table 1). The respondents had to rate the impact of each individual factor on their purchase using a 1-to-5 interval scale (1-it has the smallest impact on me, ..., 5-it has the greatest impact on me).

Table 1

The impact of the listed factors on purchasing decisions

\begin{tabular}{|l|ccc|}
\hline Name & $\mathrm{n}$ & Mean & Std. dev. \\
\hline Price of the product & 402 & 4.04 & 1.411 \\
\hline Constant quality of the product & 399 & 4.01 & 1.429 \\
\hline Health protective effect of the product & 402 & 3.97 & 1.384 \\
\hline Tastes associated with the product & 404 & 3.78 & 1.435 \\
\hline Origin of the product (local, import) & 391 & 3.77 & 1.393 \\
\hline The whole family loves it & 396 & 3.71 & 1.447 \\
\hline Label ensuring quality & 392 & 3.66 & 1.472 \\
\hline Appearance of the product, its aesthetic & 400 & 3.64 & 1.397 \\
\hline Label ensuring ecological origin & 402 & 3.54 & 1.466 \\
\hline Habit & 401 & 3.27 & 1.383 \\
\hline Brand of the product & 397 & 3.10 & 1.409 \\
\hline Handy, practical packaging & 397 & 3.06 & 1.377 \\
\hline Name of the production firm & 397 & 3.03 & 1.440 \\
\hline I can get it anywhere & 391 & 2.82 & 1.404 \\
\hline Promotedness of the product & 396 & 2.44 & 1.378 \\
\hline
\end{tabular}

Our first observation is that as much as $40 \%$ of the respondent can be treated as somewhat competent in purchasing ecological food products. The $10 \%$ surplus compared to those who pay close attention to their purchases points to a significant latent demand; the purchasing decisions of this layer are subconsciously influenced by the ecological origin of products. Further, it is apparent that none of the listed factors achieved overwhelmingly high or low score, which means that the adjustment of individual factors will not have significant market impact. "Price"-also featured as a purchase obstacles-is the most influential factor on shopping decision, but the advantageous "constant quality" and "health benefit" factors are just following it. Based on the survey, the factors which have the smallest impact on shopping decisions are the degree of promotion, the accessibility of products and the name of the production firm. 


\author{
(online) $=$ ISSN $2285-3642$ \\ ISSN-L = 2285- 3642 \\ Journal of Economic Development, Environment and People \\ Volume 4, Issue1, 2015 \\ URL: http://jedep.spiruharet.ro \\ e-mail: office jedep@spiruharet.ro
}

The cause of this phenomenon might be that compared to regular products, consumers perceive organic ones as special, which do not land in their carts due to advertisements; while as regards the point of purchase, they demand that it must signal trust. This might be related to the branding of the production firms, since there are not any widespread organic brands in Hungary, and none of the firms aim at emphasizing their own name. The labeling of ecological products is only at the middle of the listing, which explicitly refers to the lack of information, and as a result it valorizes those aspects which aid identification (without taking the anomalies identified as the causes of refusal into account).

Our next question was about the point of purchase. The interviewees were asked to mark for each listed channel whether they mostly, occasionally or never buy ecological foods products there (Figure 3).

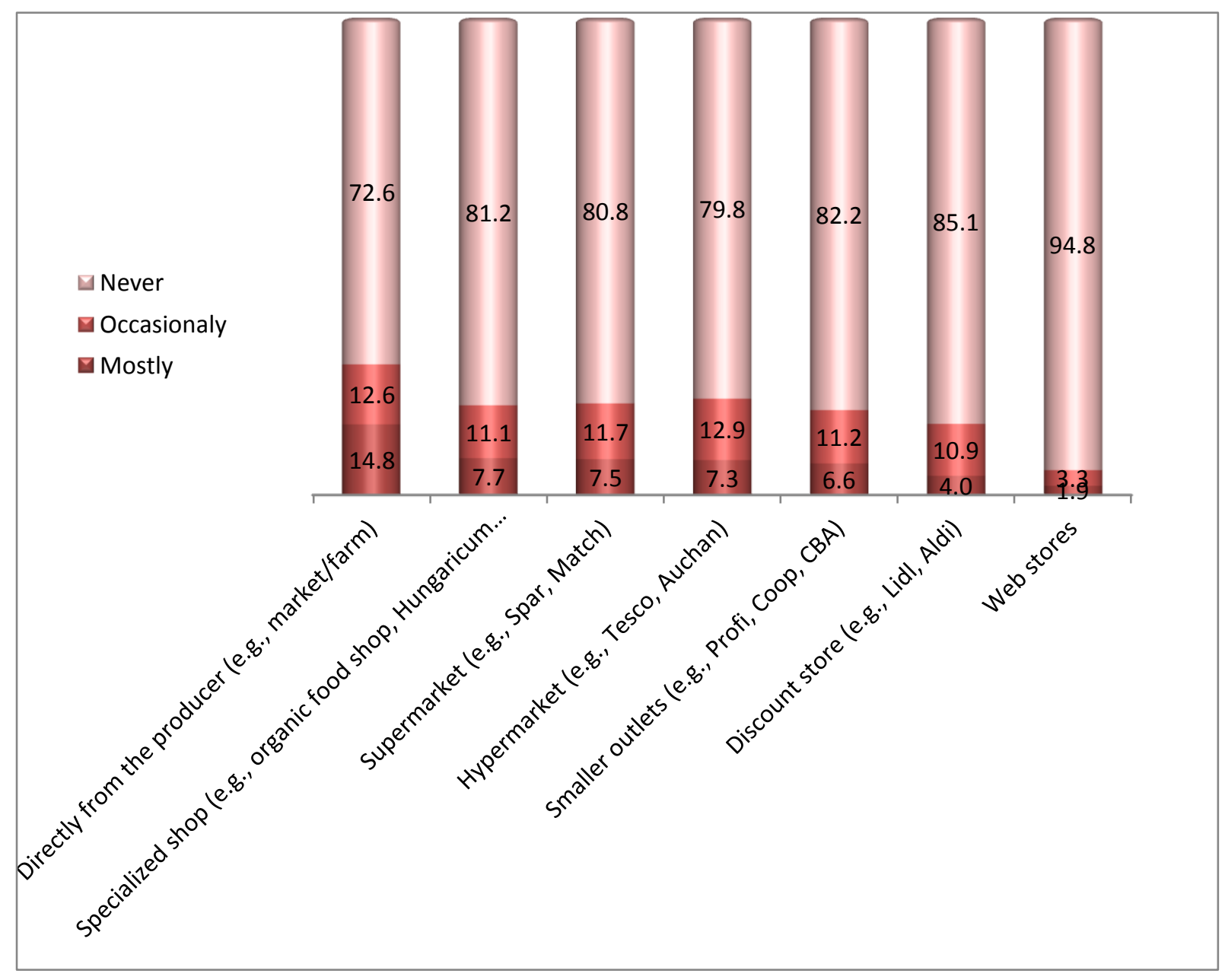

Fig. 3: Frequency of choosing different outlet types for purchasing organic foods, $\%(n=1000)$ 


\author{
(online) $=$ ISSN $2285-3642$ \\ ISSN-L = 2285- 3642 \\ Journal of Economic Development, Environment and People \\ Volume 4, Issue 1, 2015 \\ URL: http://jedep.spiruharet.ro \\ e-mail: office jedep@spiruharet.ro
}

Since organic foods have a sort of "trust product" character, it is not surprising that the largest portion of respondents usually buy these directly from the producers. For the consumers/customers it is hard to verify each criteria of organic food products-e.g. that they are free of plant-protecting agents, pesticides or hormones-thus trust for the producers is valorized. After the producers, the various specialist shops follow, which were also shown to be popular in earlier studies (Hamm et al., 2002; Schaak, 2013, Zagata, 2012). The different super and hypermarkets and smaller outlets were almost equally popular, which refers to the increasing accessibility of organic products. In the recent years, organic foods began to appear on the shelves of different discount stores in Hungary, $14.9 \%$ of the respondents maintained that they buy products from these outlets with some frequency. Purchasing from web stores is the least favored option; the operators of such outlets should expect orders for specialties and for earlier tested products.

The next question in line aimed to investigate the location where ones' purchasing decisionsare made (Figure 4).

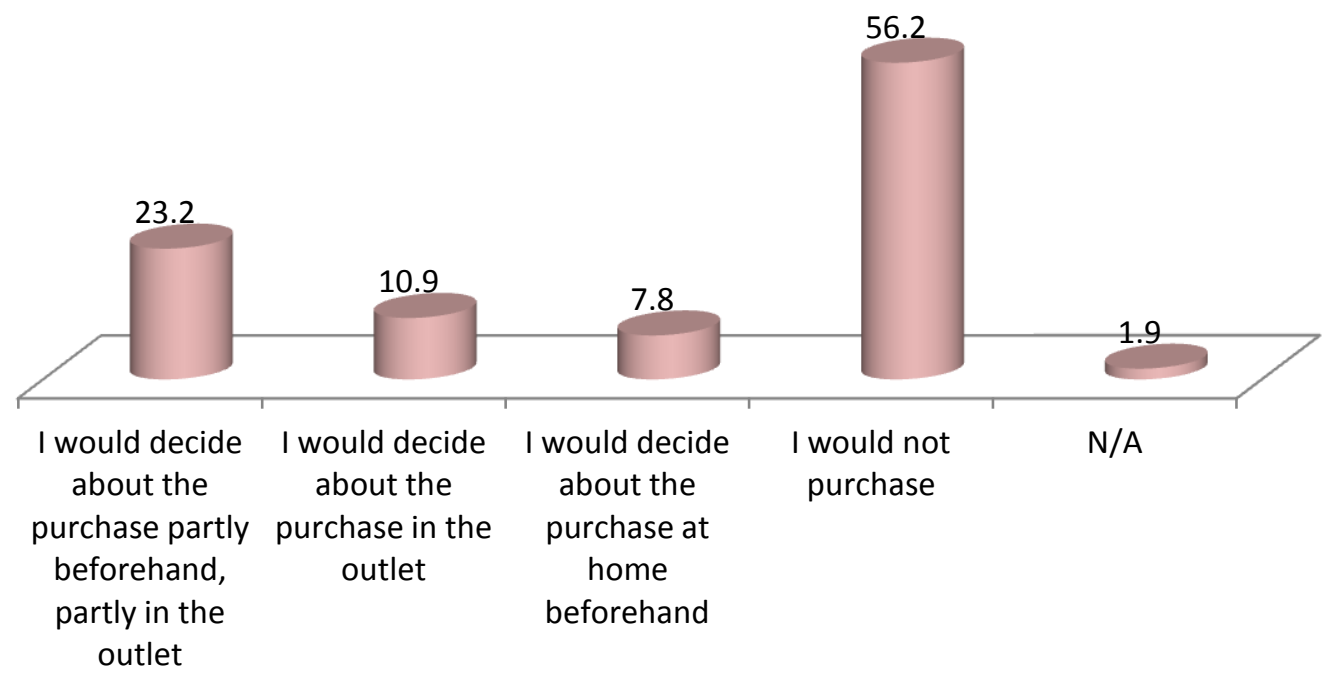

Fig. 4: Place of making purchasing decisions about organic food products, $\%(n=1000)$

Those who buy organic food products, predominantly decide about their purchase in the outlets, which highlights the importance of in-store advertising in the case of these products. Packaging, placement, shelf facing and the various POP/POS tools might have a profound impact on sales. The opinion of Hempfling (2004) seems to reinforce our observation: "I don't like it when organic products are hidden in one of the corners. If this happens, I feel that I'm sorted out, and I withdraw from buying anything."In case of direct sale, the appearance of the product (freshness and attractive packaging), the possibility to test it (taste it) and the recommendation of the producer might be useful. 


\author{
(online) = ISSN $2285-3642$ \\ ISSN-L = $2285-3642$ \\ Journal of Economic Development, Environment and People \\ Volume 4, Issue1, 2015 \\ URL: $\underline{\text { http://jedep.spiruharet.ro }}$ \\ e-mail: office jedep@spiruharet.ro
}

\title{
4. Conclusions
}

It is safe to state that there is potential demand for ecological food products in Hungary. Our results indicate that the most serious obstacles of organic food products are the lack of trust, the lack of information, the high prices and the observed insufficiencies of outlets. Although the proportion of conscious consumers is small, it significantly exceeds the current market share of the products. To exploit all possibilities, our most important insights are the following:

- One strategy could be to provide organic products at a lower price to gain and keep price-sensitive consumers. Consumers' attention could be attracted via shelf labels, wobblers, distinctive labels, free samples, and regular (but not exaggerated) discounts.

- Another strategic solution is to sell fresh products from local/regional sources more frequently, which could help strengthen consumers trust and patriotism besides providing multiple sources for inventory acquisition. The aim of in-store marketing in this case is to affirm the ethical behaviour of retailer; the applied tools are source labels and a layout emphasizing freshness. The staff has an important role, because they have to provide assistance to consumers in addition to continuously monitoring and restocking the shelves.

- The third strategy could help retailers keep or increase their market share. This approach involves increasing the selection of high quality (premium) organic products. The most important applied marketing tools here are product placement and experience. To achieve good results, organic products must be placed next to the main shopping avenues, and secondary placements are also necessary. It is advisable to create a home-like atmosphere with soft lighting and background music and to give customers the opportunity to sample the products. Guidance also has an important role here; it should focus on nutrition benefits and the unique qualities of different products.

\section{Acknowledgements}

This research was supported by the European Union and the State of Hungary, co-financed by the European Social Fund in the framework of TÁMOP 4.2.4. A/2-11-1-2012-0001 'National Excellence Program'.

\section{References}

[1] Biokontroll Hungária Nonprofit Ltd.: Évesjelentések (Yearly reports) Budapest, 1998-2012.

[2] Costanigro, M.; McFadden, D. T.; Kroll, S.; Nurse, G. An in-store valuation of local and organic apples: the role of social desirability. Agribusiness, 2011, 27: 465-477.

[3] Czeller G.Azökológiaigazdálkodáshelyzete a Dél-Dunántúlirégióban (Organic farming in the Transdanubian Region) Kaposvári Egyetem, Kaposvár, 2009.

[4] Gauvrit, L. And Schaer, B. A glimpse on organic markets in Eastern Europe. Presentation on BiofachNürnberg, 2013. 


\author{
(online) $=$ ISSN $2285-3642$ \\ ISSN-L = $2285-3642$ \\ Journal of Economic Development, Environment and People \\ Volume 4, Issue 1, 2015 \\ URL: $\underline{\text { http://jedep.spiruharet.ro }}$ \\ e-mail: office jedep@spiruharet.ro
}

[5] Gfk Hungária.Közép- ésKelet-Európafogyasztói. (Consumers of Central- and Easten Europe) Available at http://hvg.hu/gazdasag.hazai/20051116genkezelt/page3.aspx (last accessed 12 January 2011), 2005.

[6] Gerwin, D. haracteristics of the market for organic products. In: Organic market review: Observations and experiences from the Czech Republik, Hungary and Poland. Phare research, 1998, pp 1-32.

[7] Haas, R, Sterns, J., Meixner, O.; Nyob, D-I.; Traar V. Do US Consumers' Perceive Local and Organic Food Differently? An Analysis Based on Means-End Chain Analysis and Word Association. Int. J. Food System Dynamics2013, 4(3): 214-226.

[8] Hamm, U., Gronefeld, F. And Halpin, D. Analysis of the European market for organic food.OMlaRD, Wales, 2002, pp. 1-135.

[9] Hempfling, G. Mit gezielten Massnahmen den Absatz erhöhen. (Increase sales with targeted measures) Ökologie\&Landbau.2004, 32 (3): 33-35

[10] Malhotra, N.K. Marketingkutatás. (Marketing Research) Hungary: Academic Publisher, Budapest, 2008.

[11] Milestad, R., Bartel-Kratochvil, R.; Leitner, H.; Axmann, P. (2010): Being close: The quality of social relationships in a local organic cereal and bread network in Lower Austria.Journal of Rural Studies. 2010, 26: 228-240.

[12] Panyor, Á. A különlegesélelmiszerekpiacnövelésilehetőségeimegkérdezésektükrében. (The possibilities to increase consumption of special foods in the mirror of questionnaires)BudapestiCorvinusEgyetem, Budapest, 2007, pp. 1112.

[13] Schaack, D. News about the organic market in Germany 2012. Presentation on BiofachNürnberg 2013.

[14] Sahota, A. The global market for organic food and drink. WILLER, H. AND KLICHER, L. (Eds.), The world of organic agriculture: Statistics and emerging trends. FiBL-IFOAM-ITC Bonn, Frick and Geneva, 2009, pp. 59-64.

[15] Szakály, S.Táplálkozásidilemmákésazélelmiszerekfejlesztésénekvilágstratégiaiirányai. (Consumption dilemmas and strategies in food-development) Élelmiszer, táplálkozásés marketing.2004, 1 (1-2): 15-24.

[16] Szente, V. A bizalommegítéléseaz ökoélelmiszerek piacán. (Judgment of trust on the market of organic foods) Élelmiszer, táplálkozásés marketing.2009, 6 (1-2): 59-63.

[17] Willer, H. and Lernoud, J.: The European Market for Organic Food 2011. Presentation on BiofachNürnberg 2013.

[18] Zagata, L. (2012): Consumers' beliefs and behavioural intentions towards organic food. Evidence from the Czech Republic. Appetite. 2012, 59 81-89. 